\title{
Short communication: Physicochemical and antioxidant properties of milk supplemented with red ginseng extract
}

\author{
J. E. Jung, ${ }^{*}$ H. J. Yoon, ${ }^{*}$ H. S. Yu, ${ }^{*}$ N.-K. Lee, ${ }^{*} H .-S . ~ J e e, \dagger$ and H.-D. Paik ${ }^{*}{ }^{1}$ \\ *Department of Food Science and Biotechnology of Animal Resources, Konkuk University, 120 Neungdong-ro, Gwangjin-gu, Seoul 143-701, \\ Korea \\ †Food R\&D Center, Ilhwa Co. Ltd., 25Angol-ro, 56 Beon-gil, Guri-si, Gyeonggi-do 471-711, Korea \\ ‡Bio/Molecular Informatics Center, Konkuk University, 120 Neungdong-ro, Gwangjin-gu, Seoul 143-701, Korea
}

\begin{abstract}
This study investigated the effect of red ginseng extract (RGE) on the physicochemical properties, sensory test, and antioxidant activity of milk. The milk samples with RGE added at $0.5,1,1.5$, and $2 \%$ were analyzed during storage at $4^{\circ} \mathrm{C}$. The physicochemical properties included composition of milk, $\mathrm{pH}$, titratable acidity, and color. The antioxidant activity of milk samples was determined using the 2,2-diphenyl-1-picrylhydrazyl method, $\beta$-carotene bleaching assay, and ferric thiocyanate assay. An increase in the amount of RGE in milk resulted in an increase of lactose and total solids content, titratable acidity, and $a^{*}$ and $b^{*}$ values, whereas fat and protein contents remained unchanged. Also, $\mathrm{pH}$ and $\mathrm{L}^{*}$ value decreased. The antioxidant activity of milk samples supplemented with RGE was higher than that of the control sample. Sensory evaluation was performed using a quantitative descriptive analysis. Two types of samples were used: (1) sterilized milk fortified with RGE $(0.5,1,1.5$, and $2 \%)$ and (2) $2 \%$ RGE, $2 \%$ RGE with oligosaccharide, and 2\% RGE with oligosaccharide and cyclodextrin. The addition of oligosaccharide and cyclodextrin could effect an increase of sweetness, a decrease of bitterness and flavor of RGE, and aftertaste. Therefore, milk supplemented with RGE could be useful as a functional food.
\end{abstract}

Key words: milk fortified with red ginseng extract, physicochemical property, antioxidant activity, sensory test

\section{Short Communication}

Ginseng (the root of Panax ginseng C.A. Meyer, family Araliaceae) has been used as a traditional medicine for preventive and therapeutic purposes in Asian countries for more than 2,000 years. Ginseng contains

Received June 11, 2014.

Accepted October 4, 2014.

${ }^{1}$ Corresponding author: hdpaik@konkuk.ac.kr bioactive molecules such as acidic polysaccharides, ginsenosides, proteins, and phenolic compounds. Ginseng has 2 common types in the herbal-supplement market according to the processing method, namely white and red ginseng. White ginseng is obtained by peeling and then air drying fresh ginseng, and red ginseng is manufactured by steaming fresh ginseng at 98 to $100^{\circ} \mathrm{C}$ without peeling for a reasonable time and then drying until the moisture content is less than $15 \%$. The steaming process leads to significant changes in the chemical constituents such as the ginsenosides that are responsible for many of the biological activities of ginseng (Lee et al., 2013; Gui and Ryu, 2014). Korean red ginseng is reported to have therapeutic potential in Alzheimer's disease, diabetes, cancer, and cardiovascular diseases, via its antioxidant, antithrombotic, antihyperlipidemic, and anticancer properties (Lee and Park, 2014). Ginseng and red ginseng extract (RGE) of beverages is allowed to more than $0.15 \%$ contents by the Korean Food and Drug Agency (2014).

Milk is a complex mixture of specific bioactive proteins, lipids, saccharides, and bioactive substances including immunoglobulin, enzymes, antimicrobial peptides, oligosaccharides, hormones, cytokines, and growth factors (Pouliot and Gauthier, 2006). Dairy products and their components have various functions, such as a positive role in bone health, reducing the risk of certain types of cancer, enhancing immunity, improving intestinal health, and enhancing nutrient absorption (Yildiz, 2010). Milk production worldwide is estimated to increase from $692,000,000$ tons in 2010 to $827,000,000$ tons in 2020 (PMMI, 2013). Over the past decade, consumer habits have gradually shifted toward healthier food choices. This trend has resulted in the development of new dairy products. These products have been marketed as dairy products containing n-3, phytosterols, isoflavins, CLA, minerals, and vitamins (Özer and Kirmaci, 2010).

The aim of this study was to formulate a functional milk beverage by evaluating the physicochemical properties and sensory attributes of milk and its compo- 
nents. In addition, its functional properties were identified through the evaluation of antioxidant activity of milk fortified with red ginseng extract.

Commercially available milk was purchased from Seoul Milk Co. (Seoul, Korea), and RGE was purchased from Fine Korea Co. (Seoul, Korea). Samples were obtained by mixing RGE in milk at different concentrations $(0.5,1,1.5$, and $2 \%)$. Samples were taken at 0,1 , $6,15,22$, and $31 \mathrm{~d}$ while being stored at $4^{\circ} \mathrm{C}$ to evaluate the physicochemical and microbial properties.

The samples were analyzed for $\mathrm{pH}$, titratable acidity, color, and composition. The $\mathrm{pH}$ value was determined with a $\mathrm{pH}$ meter in a $10-\mathrm{mL}$ sample. The titratable acidity of the milk samples was measured using the method described by Collins et al. (1991). Each milk sample $(10 \mathrm{~mL})$ was diluted in $40 \mathrm{~mL}$ of distilled water and titrated until pH reached 8.1 using $0.1 \mathrm{~N} \mathrm{NaOH}$. The color was measured with a colorimeter (Chroma Meter CR-400 series; Konica Minolta Sensing Inc., Tokyo, Japan). Milk samples were measured (20 mL) into a Petri dish for color analysis. The general composition of milk such as protein, fat, lactose, and total solids content were measured using a MilkoScan minor (Type 78110; Foss Analytical A/S, Hillerød, Denmark). Viable bacterial cells were counted using the spreading plate method with plate count agar. The plates were incubated at $37^{\circ} \mathrm{C}$ for $3 \mathrm{~d}$.

Sensory evaluation of samples was carried out at $1 \mathrm{~d}$ using multisample difference tests-block designs. Samples were of 2 types: the first was milk fortified with RGE $(0.5,1,1.5$, and $2 \%)$ and the second was A milk (2\% RGE), B milk ( $2 \%$ RGE + oligosaccharide), and $\mathrm{C}$ milk $(2 \%$ RGE + oligosaccharide + cyclodextrin). Milks A, B, and $\mathrm{C}$ were prepared to mix with RGE, oligosaccharide, and cyclodextrin and then the mixture was sterilize at $95^{\circ} \mathrm{C}$ for $10 \mathrm{~min}$. Oligosaccharide and cyclodextrin were added in milk to reduce the bitter taste of RGE. A trained panel of 17 members was composed of adult males (8, age ranged from 20 to 30) and females (9, aged from 20 to 30 ). The sensory evaluations were carried out using quantitative descriptive analysis (Lawless and Heymann, 1999). The quantitative descriptive analysis investigated sweetness, bitterness, flavor of milk and RGE, and aftertaste of milk and RGE, having a graphic line scale.

Milk samples were diluted 2-fold in methanol and heated at $30^{\circ} \mathrm{C}$ for $1 \mathrm{~h}$ in a water bath. Samples were centrifuged at $20,760 \times g$ at $4^{\circ} \mathrm{C}$ for 10 min and filtered through filter papers (Whatman No. 1). The solvent was removed using a rotary evaporator (EYELA N-1000V, Tokyo, Japan) at $45^{\circ} \mathrm{C}$. Samples were freeze-dried and stored at $-20^{\circ} \mathrm{C}$ until use (Chung et al., 2010). The antioxidant activity was investigated using 3 methods: 1,1-diphenyl-2-picrylhydrazyl (DPPH) radical scav- enging activity, $\beta$-carotene bleaching assay, and ferric thiocyanate (FTC) assay.

The DPPH radical scavenging activity was used to measure antioxidant activity. The method described by Savikin et al. (2009), with modifications, was used to assay the DPPH scavenging activity. A $0.2-\mathrm{mL}$ aliquot from 25 and $50 \mathrm{mg} / \mathrm{mL}$ samples was mixed with $1 \mathrm{~mL}$ of $0.04 \mathrm{mg} / \mathrm{mL}$ DPPH solution. After being placed at room temperature for $15 \mathrm{~min}$ in the dark, absorbance was determined on a spectrophotometer at $517 \mathrm{~nm}$.

A $\beta$-carotene bleaching assay was carried out according to the method described by Shon (2003) with some modifications. Briefly, $2 \mathrm{mg}$ of $\beta$-carotene was dissolved in $10 \mathrm{~mL}$ of chloroform and mixed with $44 \mu \mathrm{L}$ of linoleic acid and $200 \mu \mathrm{L}$ of Tween 80 . Next, $5 \mathrm{~mL}$ of solution was pipetted into a round-bottomed flask and evaporated to remove chloroform at $40^{\circ} \mathrm{C}$. Then, the mixture was diluted with $100 \mathrm{~mL}$ of distilled water. A $500-\mu \mathrm{L}$ aliquot of sample was added to $4.5 \mathrm{~mL}$ of emulsion and incubated at $50^{\circ} \mathrm{C}$ in a water bath. Absorbance was measured at $470 \mathrm{~nm}$ using a spectrophotometer, at zero time, and continued until the color of $\beta$-carotene disappeared.

Antioxidant activity was determined with FTC using a modification of the method described by Lee et al. (2004). A 100- $\mu \mathrm{L}$ aliquot of the sample was mixed with $400 \mu \mathrm{L}$ of phosphate buffer $(40 \mathrm{mM}, \mathrm{pH} 7.0), 200 \mu \mathrm{L}$ of linoleic acid $(25 \mathrm{mg} / \mathrm{mL}$ in ethanol), and $200 \mu \mathrm{L}$ of distilled water. The reaction mixture was incubated in the dark at $37^{\circ} \mathrm{C}$, and the absorbance was read at intervals of $0,24,48$, and $72 \mathrm{~h}$. To measure the absorbance, $0.1 \mathrm{~mL}$ of the reaction mixture was added to $4 \mathrm{~mL}$ of ethanol $(70 \%)$ and $0.1 \mathrm{~mL}$ of ammonium thiocyanate (30\%). After $3 \mathrm{~min}, 0.1 \mathrm{~mL}$ of $\mathrm{FeCl}_{2}(20 \mathrm{mM}$ in $3.5 \%$ $\mathrm{HCl})$ was added, and the absorbance was measured at $500 \mathrm{~nm}$.

Three replications were performed for all tests. The data obtained were analyzed statistically using SPSS statistical software program version 18 (SPSS Inc., Chicago, IL). Differences among groups were determined with ANOVA and Duncan's multiple-range test.

The control milk sample was found to contain $4.01 \%$ fat, $3.10 \%$ protein, $4.58 \%$ lactose, and $12.55 \%$ total solids (Table 1). Milk has been reported to generally contain 3.62 to $4.77 \%$ fat, 2.89 to $3.56 \%$ protein, 4.52 to $4.69 \%$ lactose, and 12.31 to $13.31 \%$ total solids (Chen et al., 2014). The composition of RGE was as follows: carbohydrate, protein, fat, and polysaccharide content of $46.3,11.3,0.8$, and $15.4 \%$, respectively. Especially, lactose of RGE showed $17.86 \%$ by MilkoScan. Fat content of control and RGE-supplemented milk was approximately $4.00 \%$, and protein content was approximately $3.12 \%$. Content of lactose and total solids was 4.58 to $5.17 \%$ and 12.55 to $13.04 \%$, respectively. An 
Table 1. Nutritive components of milk supplemented with red ginseng extract (means \pm SD)

\begin{tabular}{|c|c|c|c|c|}
\hline \multirow{2}{*}{$\begin{array}{l}\text { Milk } \\
\text { sample }^{1}\end{array}$} & \multicolumn{4}{|c|}{ Chemical composition (\%) } \\
\hline & Fat & Protein & Lactose & Total solids \\
\hline Control & $4.01 \pm 0.00^{\mathrm{b}}$ & $3.10 \pm 0.01^{\mathrm{a}}$ & $4.58 \pm 0.01^{\mathrm{a}}$ & $12.55 \pm 0.01^{\mathrm{a}}$ \\
\hline $\mathrm{RGM}_{0.5}$ & $3.99 \pm 0.01^{\mathrm{a}}$ & $3.11 \pm 0.03^{\mathrm{ab}}$ & $4.74 \pm 0.03^{\mathrm{b}}$ & $12.70 \pm 0.05^{\mathrm{b}}$ \\
\hline $\mathrm{RGM}_{1}$ & $3.98 \pm 0.02^{\mathrm{a}}$ & $3.12 \pm 0.02^{\mathrm{bc}}$ & $4.89 \pm 0.03^{\mathrm{c}}$ & $12.80 \pm 0.02^{\mathrm{c}}$ \\
\hline $\mathrm{RGM}_{15}^{1}$ & $3.99 \pm 0.02^{\mathrm{a}}$ & $3.14 \pm 0.02^{\mathrm{c}}$ & $5.05 \pm 0.03^{\mathrm{d}}$ & $12.95 \pm 0.03^{\mathrm{d}}$ \\
\hline $\mathrm{RGM}_{2}$ & $4.00 \pm 0.01^{\mathrm{ab}}$ & $3.12 \pm 0.00^{\mathrm{bc}}$ & $5.17 \pm 0.02^{\mathrm{e}}$ & $13.04 \pm 0.02^{\mathrm{e}}$ \\
\hline
\end{tabular}

${ }^{a-e}$ Mean values with different superscripts within a single column are significantly different $(P<0.05)$.

${ }^{1} \mathrm{Control}=$ milk without red ginseng extract; $\mathrm{RGM}_{0.5}=$ milk with $0.5 \%$ red ginseng extract; $\mathrm{RGM}_{1}=$ milk with $1 \%$ red ginseng extract; $\mathrm{RGM}_{1.5}=$ milk with $1.5 \%$ red ginseng extract; $\mathrm{RGM}_{2}=$ milk with $2 \%$ red ginseng extract.

increase in concentration of RGE in milk resulted in an increase in lactose and total solids content, whereas fat and protein content were unchanged. Therefore, we found that lactose and total solids content in milk were influenced by RGE concentration.

The $\mathrm{pH}$, titratable acidity, and color values are presented in Table 2 . The $\mathrm{pH}$ value and titratable acidity were found to be from 6.72 to 6.25 and from 0.10 to $0.22 \%$, respectively. Therefore, freshness of used milk was demonstrated using $\mathrm{pH}$ and titratable acidity. When the concentration of RGE was increased, the $\mathrm{pH}$ value decreased, whereas titratable acidity increased. The $\mathrm{L}^{*}, \mathrm{a}^{*}$, and $\mathrm{b}^{*}$ values indicate changes from darkness to lightness, greenness to redness, and blueness to yellowness, respectively. Compared with the milk samples, the $\mathrm{L}^{*}$ values decreased from 93.36 to 85.08; however, $\mathrm{a}^{*}$ and $\mathrm{b}^{*}$ values increased from -3.19 to -0.07 and 5.09 to 17.82 , respectively, when the concentration of RGE increased from 0 to $2 \%$. In correlation with the amount of RGE, lightness decreased, whereas yellowness and redness increased. Therefore, the color values of the milk samples were affected by the addition of RGE. Kwak et al. (2008) reported that the $\mathrm{pH}$ value of red ginseng water extract was 4.7 , and the color values of $\mathrm{L}^{*}, \mathrm{a}^{*}$, and $\mathrm{b}^{*}$ were $85.75,-0.86$, and 27.68, respectively. Therefore, we found that the $\mathrm{pH}$, titratable acidity, and color values of milk were affected by RGE.

The $\mathrm{pH}$ value, titratable acidity, and microbial properties in the samples from control milk as well as milk supplemented with $2 \%$ RGE were determined during storage for up to $31 \mathrm{~d}$. Results showed that the $\mathrm{pH}$ value and titratable acidity were not significantly affected during storage $(P<0.05)$, except for the $\mathrm{pH}$ value of the control, which decreased slightly during storage. The microbial property was determined using the platecount-agar method to evaluate the level of contamination of milk during storage. No colony was detected on plate count agar. Bermúdez-Aguirre et al. (2010) reported characteristics of strawberry-flavored milk. The $\mathrm{pH}$ values of strawberry-flavored milk were decreased from 7 to 5 because of production of lactic acid and chemical reactions during storage. In this study, the $\mathrm{pH}$ value of RGE milk decreased because the $\mathrm{pH}$ value may have been affected by chemical reaction; however, our data did not detect an increase in lactic acid.

The milk products designated as A, B, and $\mathrm{C}$ did not show significant differences $(P>0.05)$ in all sensory attributes (data not shown). Among these, milk-product $\mathrm{C}$ showed strong sweetness and weak bitterness, flavor of RGE, and aftertaste of RGE. Our study results of the sensory evaluation were similar to those reported

Table 2. Changes of physicochemical properties of milk supplemented with red ginseng extract (means $\pm \mathrm{SD}$ )

\begin{tabular}{|c|c|c|c|c|c|}
\hline \multirow{2}{*}{$\begin{array}{l}\text { Milk } \\
\text { sample }^{1}\end{array}$} & \multirow[b]{2}{*}{$\mathrm{pH}$} & \multirow{2}{*}{$\begin{array}{c}\text { Titratable } \\
\text { acidity }(\%)\end{array}$} & \multicolumn{3}{|c|}{ Color $^{2}$} \\
\hline & & & $\mathrm{L}^{*}$ & $a^{*}$ & $b^{*}$ \\
\hline Control & $6.72 \pm 0.03^{\mathrm{e}}$ & $0.10 \pm 0.01^{\mathrm{a}}$ & $93.36 \pm 0.11^{\mathrm{e}}$ & $-3.19 \pm 0.06^{\mathrm{a}}$ & $5.09 \pm 0.20^{\mathrm{a}}$ \\
\hline $\mathrm{RGM}_{0.5}$ & $6.59 \pm 0.02^{\mathrm{d}}$ & $0.13 \pm 0.01^{b}$ & $89.89 \pm 0.04^{\mathrm{d}}$ & $-2.12 \pm 0.06^{\mathrm{b}}$ & $11.21 \pm 0.09^{b}$ \\
\hline $\mathrm{RGM}_{1}$ & $6.49 \pm 0.01^{\mathrm{c}}$ & $0.15 \pm 0.00^{\mathrm{c}}$ & $87.80 \pm 0.01^{\mathrm{c}}$ & $-1.30 \pm 0.06^{\mathrm{c}}$ & $14.20 \pm 0.03^{\mathrm{c}}$ \\
\hline $\mathrm{RGM}_{1.5}$ & $6.34 \pm 0.05^{\mathrm{b}}$ & $0.18 \pm 0.00^{\mathrm{d}}$ & $85.65 \pm 0.02^{\mathrm{b}}$ & $-0.63 \pm 0.04^{\mathrm{d}}$ & $16.29 \pm 0.02^{\mathrm{d}}$ \\
\hline $\mathrm{RGM}_{2}$ & $6.25 \pm 0.06^{\mathrm{a}}$ & $0.22 \pm 0.01^{\mathrm{e}}$ & $85.08 \pm 0.33^{\mathrm{a}}$ & $-0.07 \pm 0.07^{\mathrm{e}}$ & $17.82 \pm 0.17^{\mathrm{e}}$ \\
\hline
\end{tabular}

${ }^{\mathrm{a} e}$ Mean values with different superscripts within the same column are significantly different $(P<0.05)$.

${ }^{1}$ Control $=$ milk without red ginseng extract; $\mathrm{RGM}_{0.5}=$ milk with $0.5 \%$ red ginseng extract; $\mathrm{RGM}_{1}=$ milk with $1 \%$ red ginseng extract; $\mathrm{RGM}_{1.5}=$ milk with $1.5 \%$ red ginseng extract; $\mathrm{RGM}_{2}=$ milk with $2 \%$ red ginseng extract.

${ }^{2} \mathrm{~L}^{*}=$ darkness to lightness $(0-100) ; \mathrm{a}^{*}=$ greenness to redness $(-60-60) ; \mathrm{b}^{*}=$ blueness to yellowness $(-60-60)$. 
JUNG ET AL.

Table 3. Antioxidant activity of milk fortified with red ginseng extract (means \pm SD)

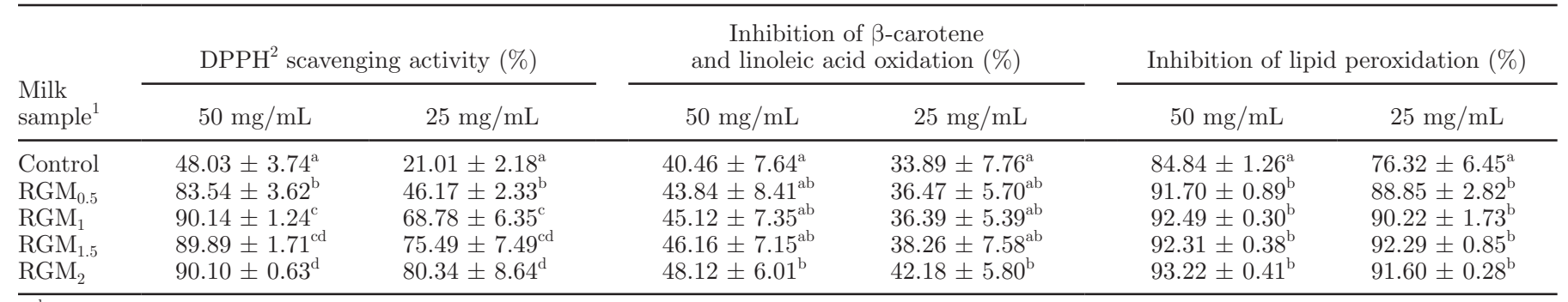

${ }^{\mathrm{a}-\mathrm{d}}$ Mean values with different superscripts within the same column are significantly different $(P<0.05)$.

${ }^{1}$ Control $=$ milk without red ginseng extract; $\mathrm{RGM}_{0.5}=$ milk with $0.5 \%$ red ginseng extract; $\mathrm{RGM}_{1}=$ milk with $1 \%$ red ginseng extract; $\mathrm{RGM} \mathrm{M}_{1.5}$ $=$ milk with $1.5 \%$ red ginseng extract; $\mathrm{RGM}_{2}=$ milk with $2 \%$ red ginseng extract.

${ }^{2} \mathrm{DPPH}=2,2$-diphenyl-1-picrylhydrazyl.

by Tárrega et al. (2012), who performed sensory evaluation of a functional milk beverage with American ginseng (Panax quinquefolius L.) using different component and additives, namely $0.1 \%$ American ginseng extract, $0.04 \%$ vanilla aroma, and $0.001 \%$ sucralose.

Table 3 shows the results from the DPPH radical scavenging activity, $\beta$-carotene bleaching assay, and FTC assay. The DPPH radical scavenging activity ranged from 21 to $80 \%$ and 48 to $90 \%$ in 25 and $50 \mathrm{mg} /$ $\mathrm{mL}$ samples, respectively. In $50-\mathrm{mg} / \mathrm{mL}$ samples, antioxidant activity was $48 \%$ in control, $83 \%$ in $0.5 \%$ RGE, and approximately $90 \%$ in 1 to $2 \%$ RGE-supplemented milk. In $25 \mathrm{mg} / \mathrm{mL}$ samples, scavenging activity gradually increased with increasing concentration of RGE, namely $21 \%$ in control, $46 \%$ in $0.5 \%$ RGE, $68 \%$ in $1 \% \mathrm{RGE}, 75 \%$ in $1.5 \% \mathrm{RGE}$, and $80 \%$ in $2 \%$ RGEsupplemented milk.

Inhibition of $\beta$-carotene and linoleic acid oxidation ranged from 33 to $42 \%$ and from 40 to $48 \%$ in 25 and $50 \mathrm{mg} / \mathrm{mL}$ samples, respectively. In $25 \mathrm{mg} / \mathrm{mL}$ samples, the $\beta$-carotene bleaching assay values were $33.89,36.47$, $36.39,38.26$, and $42.18 \%$ for milk containing $0,0.5,1,1.5$, and $2 \% \mathrm{RGE}$, respectively. In $50 \mathrm{mg} / \mathrm{mL}$ samples, values were $40.46,43.84,45.12,46.16$, and $48.12 \%$, respectively, for $0,0.5,1,1.5$, and $2 \%$ RGE-supplemented milk. Thus, we found that when the RGE concentration and sample content increased, the antioxidant effect increased.

High antioxidant activity of RGE-supplemented milk was revealed by the FTC assay. The FTC assay values ranged from 75 to $91 \%$ and from 84 to $93 \%$ in 25 and $50 \mathrm{mg} / \mathrm{mL}$ samples, respectively. We found that the antioxidant effect increased with an increase in RGE concentration as well as sample content. In $50-\mathrm{mg} / \mathrm{mL}$ samples, the inhibition of lipid peroxidation of milk containing $0,0.5,1,1.5$, and $2 \%$ RGE was $84.84,91.70$, $92.49,92.31$, and $93.22 \%$, respectively. In $25 \mathrm{mg} / \mathrm{mL}$ samples, these values were $76.32,88.85,90.22,92.29$, and $91.60 \%$, respectively.
Gad and El-Salam (2010) reported antioxidant assay of skim milk supplemented with rosemary and green tea extracts, and they determined by the DPPH radical scavenging activity and ferric reducing antioxidant power. They showed that DPPH scavenging capacity and ferric reducing antioxidant power increased with an increase in the ratio of rosemary and green tea extracts added to skim milk. Sharma et al. (2008) also reported antioxidant effects of black tea mixed with milk and sugar. Sharma's group used sample concentrations of 5, 10, 20, and $40 \mathrm{ppm}$, and antioxidant effects were determined using DPPH radical scavenging activity and $\beta$-carotene-linoleic acid assay. In our study, the difference of antioxidant effect was determined using different methods (DPPH scavenging and $\beta$-carotene bleaching assay).

The physicochemical properties of the red ginseng milk beverage were studied including the components of milk, $\mathrm{pH}$ value, titratable acidity, color, and bacterial contamination of samples during storage. From the sensory test, we found that the addition of oligosaccharide and cyclodextrin affected strong sweetness, weak bitterness, flavor of RGE, and aftertaste. Results of the antioxidant activity determined by DPPH scavenging, $\beta$-carotene bleaching assay, and FTC assay showed that the antioxidant property of milk was improved by addition of RGE.

\section{ACKNOWLEDGMENTS}

This research was supported by Technology Development Program (Grant\# 610002-03-02-SB220) through the Ministry for Food, Agriculture, Forestry and Fisheries and Priority Research Centers Program through the National Research Foundation of Korea (NRF) funded by the Ministry of Education, Science and Technology (2012-0006686), Republic of Korea. 


\section{REFERENCES}

Bermúdez-Aguirre, D., J. A. Yáñez, C. P. Dunne, N. M. Davies, and G. V. Barbosa-Cánovas. 2010. Study of strawberry flavored milk under pulsed electric field processing. Food Res. Int. 43:2201-2207.

Chen, B., M. J. Lewis, and A. S. Grandison. 2014. Effect of seasonal variation of the composition and properties of raw milk destined for processing in the UK. Food Chem. 158:216-223.

Chung, S. J., Y. R. Chu, H. Park, I. S. Jeon, and Y. S. Kang. 2010. Influence of the addition of MACA (Lepidium meyenii) hot water extract on the quality and antioxidant activity of yogurt. Korean J. Food Cult. 25:334-341.

Collins, J. L., C. B. Ebah, J. R. Mount, D. J. Demott, and F. A. Draughon. 1991. Production and evaluation of milk-sweet potato mixtures fermented with yogurt bacteria. J. Food Sci. 56:685-688.

PMMI (The Association for Packaging and Processing Technologies). 2013. Executive summary and industry perspective. Accessed November 2014. http://www.pmmi.org/files/Research/Executive Summaries/2013DairyExecSummary.pdf.

Gad, A. S., and M. H. A. El-Salam. 2010. The antioxidant properties of skim milk supplemented with rosemary and green tea extracts in response to pasteurization, homogenization and the addition of salts. Int. J. Dairy Technol. 63:349-355.

Gui, Y., and G.-H. Ryu. 2014. Effects of extrusion cooking on physicochemical properties of white and red ginseng (powder). J. Ginseng Res. 38:146-153.

Korean Food and Drug Agency. 2014. Ginseng, red ginseng beverage. Accessed Aug. 1, 2012. http://fse.foodnara.go.kr/residue/mobile/ menu_03_02.jsp?idx=44.

Kwak, Y. S., K. H. Choi, J. S. Kyung, J. Y. Won, M. H. Rhee, J. G. Lee, M. S. Hwang, S. C. Kim, C. K. Park, K. B. Song, and G. H. Han. 2008. Effects of high temperature heating on the some physicochemical properties of Korean red ginseng (Panax ginseng C.A. Meyer) water extract. J. Ginseng Res. 32:120-126.
Lawless, H. T., and H. Heymann. 1999. Sensory Evaluation of Food: Principles and Practices. Kluwer Acad., New York, NY.

Lee, J. Y., W. I. Hwang, and S. T. Lim. 2004. Antioxidant and anticancer activities of organic extracts from Platycodon grandiflorum A. De Candolle roots. J. Ethnopharmacol. 93:409-415.

Lee, S. E., and Y. S. Park. 2014. Korean red ginseng water extract inhibits COX-2 expression by suppressing p38 in acrolein-treated human endothelial cells. J. Ginseng Res. 38:34-39.

Lee, S. M., S. C. Kim, J. S. Oh, J. H. Kim, and M. K. Na. 2013. 20( $R)$ Ginsenoside Rf: A new ginsenoside from red ginseng extract. Phytochem. Lett. 6:620-624.

Özer, B. H., and H. A. Kirmaci. 2010. Functional milks and dairy beverages. Int. J. Dairy Technol. 63:1-15.

Pouliot, Y., and S. F. Gauthier. 2006. Milk growth factors as health products: Some technological aspects. Int. Dairy J. 16:1415-1420.

Savikin, K., G. Zdunic, T. Jankovic, T. Stanojkovic, Z. Juranic, and N. Menkovic. 2009. In vitro cytotoxic and antioxidative activity of Cornus mas and Cotinus coggygria. Nat. Prod. Res. 23:1731-1739.

Sharma, V., H. V. Kumar, and L. J. M. Rao. 2008. Influence of milk and sugar on antioxidant potential of black tea. Food Res. Int. 41:124-129.

Shon, M. 2003. Antioxidant and free radical scavenging activity of Phellinus baumii (Phellinus of Hymenochaetaceae) extracts. Food Chem. 82:593-597.

Tárrega, A., A. Salvador, M. Meyer, N. Feuillére, A. Ibarra, M. Roller, D. Terroba, C. Madera, J. R. Iglesias, J. Echevarria, and S. Fiszman. 2012. Active compounds and distinctive sensory features provided by American ginseng (Panax quinquefolius L.) extract in a new functional milk beverage. J. Dairy Sci. 95:4246-4255.

Yildiz, F. 2010. Development and Manufacture of Yogurt and Other Functional Dairy Products. CRC Press, New York, NY. 